\title{
Atmospheric-Pressure Cold Plasma Activating Au/P25 for CO Oxidation: Effect of Working Gas
}

\author{
Jingsen Zhang ${ }^{1}$, Lanbo Di ${ }^{1, * \mathbb{D}}$, Feng $\mathrm{Yu}^{2}{ }^{2}$, Dongzhi Duan ${ }^{1}$ and Xiuling Zhang ${ }^{1, *}$ \\ 1 College of Physical Science and Technology, Dalian University, Dalian 116622, China; \\ zhangjingsen0708@163.com (J.Z.); duandongzhi0529@163.com (D.D.) \\ 2 School of Chemistry and Chemical Engineering, Shihezi University, Shihezi 832003, China; \\ yufeng05@mail.ipc.ac.cn \\ * $\quad$ Correspondence: dilanbo@163.com (L.D.); xiulz@sina.com (X.Z.); Tel.: +86-411-8740-2712 (L.D. \& X.Z.)
}

Received: 6 August 2018; Accepted: 17 September 2018; Published: 19 September 2018

\begin{abstract}
Commercial $\mathrm{TiO}_{2}$ (P25) supported gold (Au/P25) attracts increasing attention. In this work, atmospheric-pressure (AP) cold plasma was employed to activate the Au/P25-As catalyst prepared by a modified impregnation method. The influence of cold plasma working gas (oxygen, argon, hydrogen, and air) on the structure and performance of the obtained Au/P25 catalysts was investigated. X-ray diffraction (XRD), UV-Vis diffuse reflectance spectroscopy (DRS), transmission electron microscopy (TEM), and X-ray spectroscopy (XPS) were adopted to characterize the Au/P25 catalysts. CO oxidation was used as model reaction probe to test the $\mathrm{Au} / \mathrm{P} 25$ catalyst. XRD results reveal that supporting gold and AP cold plasma activation have little effect on the P25 support. $\mathrm{CO}$ oxidation activity over the Au/P25 catalysts follows the order: Au/P25- $\mathrm{O}_{2} \mathrm{P}>\mathrm{Au} / \mathrm{P} 25-\mathrm{As}$ $>\mathrm{Au} / \mathrm{P} 25-\mathrm{ArP} \approx \mathrm{Au} / \mathrm{P} 25-\mathrm{H}_{2} \mathrm{P}>\mathrm{Au} / \mathrm{P} 25-\mathrm{AirP} . \mathrm{Au} / \mathrm{P} 25-\mathrm{AirP}$ presents the poorest CO oxidation catalytic activity among the Au/P25 catalysts, which may be ascribed to the larger size of gold nanoparticles, low concentration of active $[\mathrm{O}]_{s}$, as well as the poisoning $\left[\mathrm{NO}_{\mathrm{x}}\right]_{s}$. The poor catalytic performance of $\mathrm{Au} / \mathrm{P} 25-\mathrm{ArP}$ and $\mathrm{Au} / \mathrm{P} 25-\mathrm{H}_{2} \mathrm{P}$ is ascribed to the lower concentration of $[\mathrm{O}]_{\mathrm{s}}$ species. $100 \% \mathrm{CO}$ conversion temperatures for $\mathrm{Au} / \mathrm{P} 25-\mathrm{O}_{2} \mathrm{P}$ is $40{ }^{\circ} \mathrm{C}$, which is $30^{\circ} \mathrm{C}$ lower than that over the as-prepared $\mathrm{Au} / \mathrm{P} 25-\mathrm{As}$ catalyst. The excellent $\mathrm{CO}$ oxidation activity over $\mathrm{Au} / \mathrm{P} 25-\mathrm{O}_{2} \mathrm{P}$ is mainly attributed to the efficient decomposition of gold precursor species, small size of gold nanoparticles, and the high concentration of $[\mathrm{O}]_{\mathrm{s}}$ species.
\end{abstract}

Keywords: Au/P25; CO oxidation; atmospheric-pressure cold plasma; working gas

\section{Introduction}

Supported gold catalysts have attracted increasing research interest after the pioneering work of Haruta [1,2]. Catalytic oxidation of carbon monoxide (CO) over supported gold catalysts has been widely used in indoor air purification, polymer electrolyte membrane fuel cells, low-temperature $\mathrm{CO}$ sensors and gas mark [3-6]. Catalytic performance of the supported gold catalyst is closely related with the size of gold nanoparticles, and the support and preparation method. It is generally accepted that the optimal size of gold nanoparticles is in the range of 2-4 nm [7], and $\mathrm{TiO}_{2}$ is the most popular support due to its nontoxicity, low cost, high chemical stability, as well as the strong metal-support interaction formed in $\mathrm{CO}$ oxidation [8]. The most adopted method for synthesizing supported gold catalysts is the deposition-precipitation (DP) method. Generally adopted gold precursor $\left(\mathrm{HAuCl}_{4}\right)$ hydrolyzes in solution to form $\mathrm{Au}(\mathrm{OH})_{\mathrm{x}} \mathrm{Cl}_{4-\mathrm{x}}{ }^{-}$. Selection of the support is confined to the isoelectric point [6] to make the positive charged support to absorb the $\mathrm{Au}(\mathrm{OH})_{\mathrm{x}} \mathrm{Cl}_{4-\mathrm{x}}{ }^{-}$species at a proper rate. Consequently, a simple modified impregnation method is developed and employed to synthesize supported gold catalysts [9]. Both the deposition-precipitation method and modified impregnation 
method need a post thermal activation process, which may result in the side effect of irreversible gold particles aggregation [10,11]. Therefore, it is urgently necessary to develop an alternative low temperature technique to activate the gold catalysts.

Cold plasma can be operated close to room temperature with high energy electrons, and has been proven to be highly suitable to synthesize supported metal catalysts [12-14]. The fast and low-temperature preparation process, and the Coulomb interaction between the charged species and metal precursors ions in cold plasma are conductive to fabrication of metal nanoparticles of small sizes with high dispersion [12]. In addition, the non-thermal equilibrium property of cold plasma is beneficial to enhanced metal-support interaction, amorphous metal nanoparticles $[15,16]$, as well as metal alloy with specific structure [17,18], and metal nanoparticles with specific crystal facet [14]. Thanks to these properties, cold plasma has been successfully employed to prepare and activate gold catalysts, and it has been efficient to enhance the catalytic performance of the gold catalysts [19-25]. Deng et al. [26] used AP oxygen cold plasma to activate Au/P25 catalysts, and found the prepared catalysts exhibited enhanced activity for visible-light photocatalytic oxidation of CO. In previous work, we adopted AP hydrogen and oxygen cold plasma to synthesize $\mathrm{Au} / \mathrm{TiO}_{2}$ catalysts, and obtained high performance gold catalysts $[27,28]$. The effect of discharge time and discharge voltage on the structure and property of the $\mathrm{Au} / \mathrm{TiO}_{2}$ catalysts are also investigated and discussed [29]. The results indicate that the small size of gold nanoparticles and the high concentration of active surface oxygen species are the main reasons for the high performance. In spite of this, no system work has been carried out to investigate the influence of the cold plasma working atmosphere on the structure and performance of the supported gold catalysts.

In this work, AP cold plasma is adopted to activate the Au/P25-As catalyst prepared by a simple modified impregnation method. The influence of cold plasma working gas (oxygen, argon, hydrogen, and air) on the structure and performance of the obtained Au/P25catalysts was investigated, and the influence mechanism is discussed.

\section{Materials and Methods}

\subsection{Catalysts Preparation}

Chloroauric acid ( $\mathrm{HAuCl}_{4} \cdot 4 \mathrm{H}_{2} \mathrm{O}, \geq 99 \%$ ) purchased from Tianjin Kemiou Chemical Reagent Co. Ltd. was used as gold precursor. Commercial Degussa P25 $\mathrm{TiO}_{2}$ obtained from Germany Degussa Corporation was used as support. Aqueous ammonia solution $\left(\mathrm{NH}_{3} \cdot \mathrm{H}_{2} \mathrm{O}, 25 \%\right)$ was acquired from Liaoning Xinxing Chemical Reagent Co. Ltd. All the chemicals were used as received without any further purification.

$\mathrm{Au} / \mathrm{P} 25$ catalysts with $1 \mathrm{wt} \%$ theoretical gold loading were synthesized according to a modified impregnation method reported in a previous study [9]. First, $2.9 \mathrm{~mL}$ deionized water and $1.1 \mathrm{~mL}$ $\mathrm{HAuCl}_{4} \cdot 4 \mathrm{H}_{2} \mathrm{O}$ solution $\left(\mathrm{C}_{\mathrm{Au}}=0.01912 \mathrm{~g} \mathrm{~mL}^{-1}\right)$ were sequentially added into a $5 \mathrm{~mL}$ measuring cylinder under continuous stirring. Then, the mixed solution was transferred into a $50 \mathrm{~mL}$ beaker with $2 \mathrm{~g} \mathrm{P} 25 \mathrm{TiO}_{2}$. The mixture was stirred for a few minutes until it got light yellow and was subsequently aged at room temperature for $12 \mathrm{~h}$. The colloid was rinsed three times with $30 \mathrm{~mL}$ aqueous ammonia solution $(\mathrm{pH}=11)$ and three times with $30 \mathrm{~mL}$ deionized water in sequence. The product was collected by centrifuge at $10500 \mathrm{rpm}$ for $5 \mathrm{~min}$ after each rinse. Finally, Au/P25 catalyst was obtained by drying the product at room temperature for $24 \mathrm{~h}$ in a vacuum oven, and was designated as Au/P25-As. The $\mathrm{Au}$ content in $\mathrm{Au} / \mathrm{P} 25-\mathrm{As}$ is determined to be ca. $0.90 \mathrm{wt} \%$ by an Optima 2000DV ICP-AES (Perkin-Elmer, Boston, MA, USA).

Atmospheric-pressure (AP) dielectric barrier discharge (DBD) cold plasma with various working gases was adopted to activate the Au/P25-As catalyst, and the effect of working gas was investigated. Typically, $0.12 \mathrm{~g} \mathrm{Au} / \mathrm{P} 25-\mathrm{As}$ was activated by AP cold plasma of oxygen, hydrogen, argon, and air at the discharge voltage of $29 \mathrm{kV}$ for one minute, and the obtained catalysts were denoted as $\mathrm{Au} / \mathrm{P} 25-\mathrm{O}_{2} \mathrm{P}$, $\mathrm{Au} / \mathrm{P} 25-\mathrm{H}_{2} \mathrm{P}, \mathrm{Au} / \mathrm{P} 25-\mathrm{ArP}$ and $\mathrm{Au} / \mathrm{P} 25-\mathrm{AirP}$, respectively. Flow rate of all the working gases were 
kept at $100 \mathrm{~mL} \cdot \mathrm{min}^{-1}$. A schematic diagram of the AP DBD cold plasma device is shown in Figure 1. The quartz reactor located between high-voltage electrode and ground electrode consists of an upper quartz plate of $90 \mathrm{~mm}$ in diameter and $1 \mathrm{~mm}$ in thickness and a quartz circular groove of $4.5 \mathrm{~mm}$ in inner depth and $70 \mathrm{~mm}$ in inner diameter. Both of the electrodes are made of stainless steel. The discharge frequency and discharge voltage were observed by an oscilloscope (DPO2014, Tektronix, Beaverton, OR, USA) with a 1000:1 high voltage probe (Tektronix, P6015A, Beaverton, OR, USA).

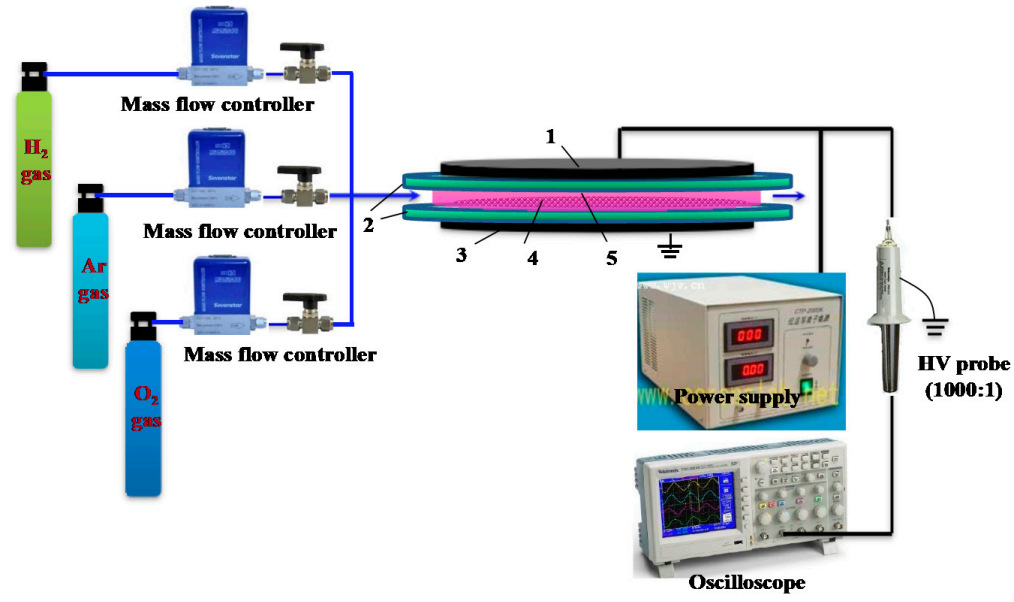

Figure 1. Schematic of the atmospheric-pressure (AP) dielectric barrier discharge (DBD) cold plasma device for activating Au/P25 catalysts. 1-discharge electrode, 2-quartz reactor, 3-ground electrode, 4-sample, 5-cold plasma.

\subsection{Catalysts Characterization}

The crystal structures of the synthesized Au/P25 catalysts were analyzed by X-ray diffraction (XRD) on a DX-2700 X-ray power diffractometer (Dandong Haoyuan, Dandong, China) with Cu $\mathrm{K} \alpha$ radiation $(\lambda=0.154 \mathrm{~nm})$ at $40 \mathrm{kV}$ and $30 \mathrm{~mA}$. Ultraviolet-Visible (UV-Vis) diffuse reflectance spectroscopy (DRS) was adopted to measure the absorption property of the samples using a U3900 spectrophotometer (Hitachi, Tokyo, Japan). Before testing, the baseline was calibrated using two pieces of $\mathrm{BaSO}_{4}$ white plates at the mode of $\mathrm{R} \%$. Transmission electron microscopy (TEM) images of the samples were collected on a HT7700 transmission electron microscope (Hitachi, Tokyo, Japan) with an accelerating voltage of $120 \mathrm{kV}$. The mean sizes of gold nanoparticles and corresponding size distribution were calculated by selecting more than 120 gold nanoparticles from TEM images. Surface chemical analyses of the samples were performed by X-ray photoelectron spectroscopy (XPS) using an ESCALAN250 X-ray photoelectron spectrometer (Thermo VG, Waltham, MA, USA) equipped with a monochromatic Al K $\alpha$ X-ray source (1486.6 eV photon energy, $150 \mathrm{~W})$. The binding energy of each element in Au/P25 catalysts was calibrated by comparing the standard XPS peak of C1s at $284.6 \mathrm{eV}$.

\subsection{Catalytic Activity Evaluation}

Catalytic activity of the Au/P25 catalyst was evaluated by $\mathrm{CO}$ oxidation in a temperature programmed quartz tube controlled by an electric furnace in the range $30-150{ }^{\circ} \mathrm{C} .50 \mathrm{mg}$ Au/P25 catalyst (40-60 mesh) was filled in the middle of a quartz tube with an inner diameter of $4 \mathrm{~mm}$. The catalyst was purged with argon for $15 \mathrm{~min}$ prior to reaction. During $\mathrm{CO}$ oxidation reaction, the synthetic gas containing 1 vol. $\% \mathrm{CO}, 20$ vol. $\% \mathrm{O}_{2}$ and balance $\mathrm{N}_{2}$ was fed into the quartz tube at a flow rate of $20 \mathrm{~mL} \cdot \mathrm{min}^{-1}$. CO concentration was dynamically monitored by a $\mathrm{S710} \mathrm{CO}_{\mathrm{x}}$ analyzer (SICK-MAIHAK, Waldkirch, Germany). CO conversion $\left(X_{C O}\right)$ is defined using the following equation:

$$
X_{\mathrm{CO}}=\frac{C_{\mathrm{CO}}^{\text {in }}-C_{\mathrm{CO}}^{\text {out }}}{C_{\mathrm{CO}}^{\text {in }}} \times 100 \%
$$


where $C_{\mathrm{CO}}^{\mathrm{in}}$ and $C_{\mathrm{CO}}^{\text {out }}$ represent the volume concentrations of $\mathrm{CO}$ before and after reaction at a certain temperature, respectively.

\section{Results and Discussion}

Figure 2 presents the XRD patterns of $\mathrm{Au} / \mathrm{P} 25$ catalysts as prepared and activated by AP cold plasma with different working gases, as well as P25 support. All the diffraction peaks in the samples can be well indexed as anatase $\mathrm{TiO}_{2}$ (JCPDS no.21-1272) and rutile $\mathrm{TiO}_{2}$ (JCPDS no. 21-1276). The diffraction peaks at $39.15^{\circ}$ and $44.05^{\circ}$ can be detected for all the samples including the pure $\mathrm{P} 25 \mathrm{TiO}_{2}$ support, which corresponds to the anatase $\mathrm{TiO}_{2}$ (200) and (210) planes (JCPDS no.21-1272). They are very close to the diffraction peaks of $\mathrm{Au}(111)$ and (220) planes in the positions of $38.18^{\circ}$ and $44.39^{\circ}$ (JCPDS no. 04-0784), respectively. Compared to the pure $\mathrm{P} 25 \mathrm{TiO}_{2}$ support, the intensity of these diffraction peaks are decreased for the Au/P25 samples ascribing to the supporting of gold species. Therefore, these peaks should be attributed to anatase $\mathrm{TiO}_{2}$ rather than metallic gold. In addition, the nominal loading amount of gold is $1 \mathrm{wt} \%$. The gold species are not detected in the XRD patterns which also indicates that small size of gold species with high dispersion are synthesized, which is consistent with the TEM analysis $\left(D_{\mathrm{Au}}=3-4 \mathrm{~nm}\right.$ ) (Figure 3). Because cold plasma is generated by high-voltage discharge, many researchers are afraid that it may change or destroy the treated materials. Therefore, the influence of AP cold plasma on the structure of $\mathrm{P} 25 \mathrm{TiO}_{2}$ support is discussed based on the XRD data. Positions of the strongest characteristic diffraction peaks of the samples, anatase (101) and rutile (110), were summarized in Table 1 . There is no obvious difference among them. To further investigate the influence of supporting gold and AP cold plasma activation on the structure of the P25, the weight fraction and average crystallite size of anatase $\mathrm{TiO}_{2}$ and rutile $\mathrm{TiO}_{2}$ were also determined, as summarized in Table 1 . The weight fraction of rutile $\mathrm{TiO}_{2}\left(W_{\text {rutile }}\right)$ was obtained according to the following formula [30]:

$$
W_{\text {rutile }}=\frac{I_{\text {rutile }}}{0.884 I_{\text {anatase }}+I_{\text {rutile }}}
$$

where $I_{\text {anatase }}$ and $I_{\text {rutile }}$ represent the diffraction intensity of anatase (101) and rutile (110), respectively. The average weight fraction of rutile is $18.2 \%$ according to the data listed in Table 1 . The crystallite size of anatase $\mathrm{TiO}_{2}\left(D_{\text {anatase }}\right)$ and rutile $\mathrm{TiO}_{2}\left(D_{\text {anatase }}\right)$ were obtained according to the Scherrer equation using the characteristic data of anatase (101) and rutile (110). The average crystallite sizes of anatase and rutile $\mathrm{TiO}_{2}$ are $21.3 \mathrm{~nm}$ and $29.2 \mathrm{~nm}$, respectively. These results indicate that supporting gold and AP cold plasma activation have little effect on the structure of the P25 support.

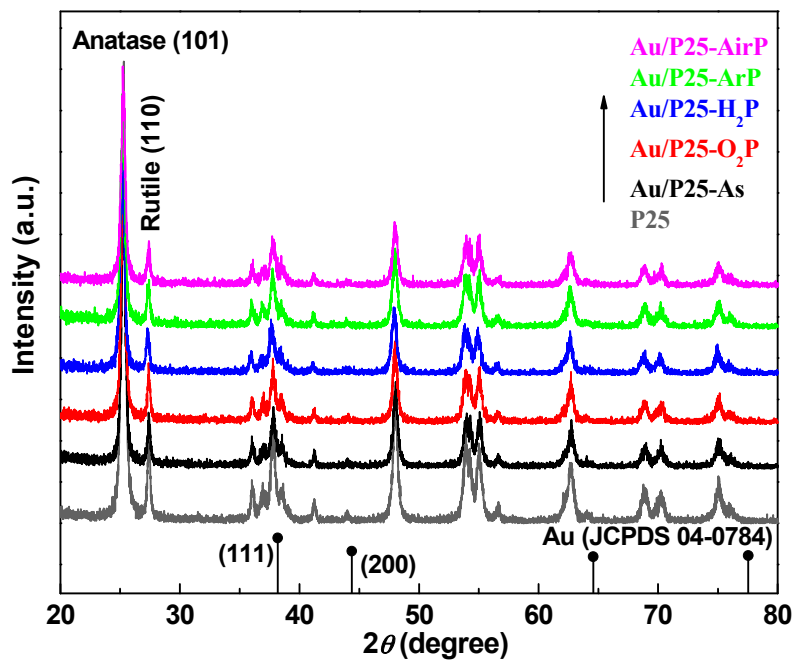

Figure 2. X-ray diffraction (XRD) patterns of the Au/P25 catalysts as prepared and activated by AP cold plasma using various working gases, as well as P25 support. 

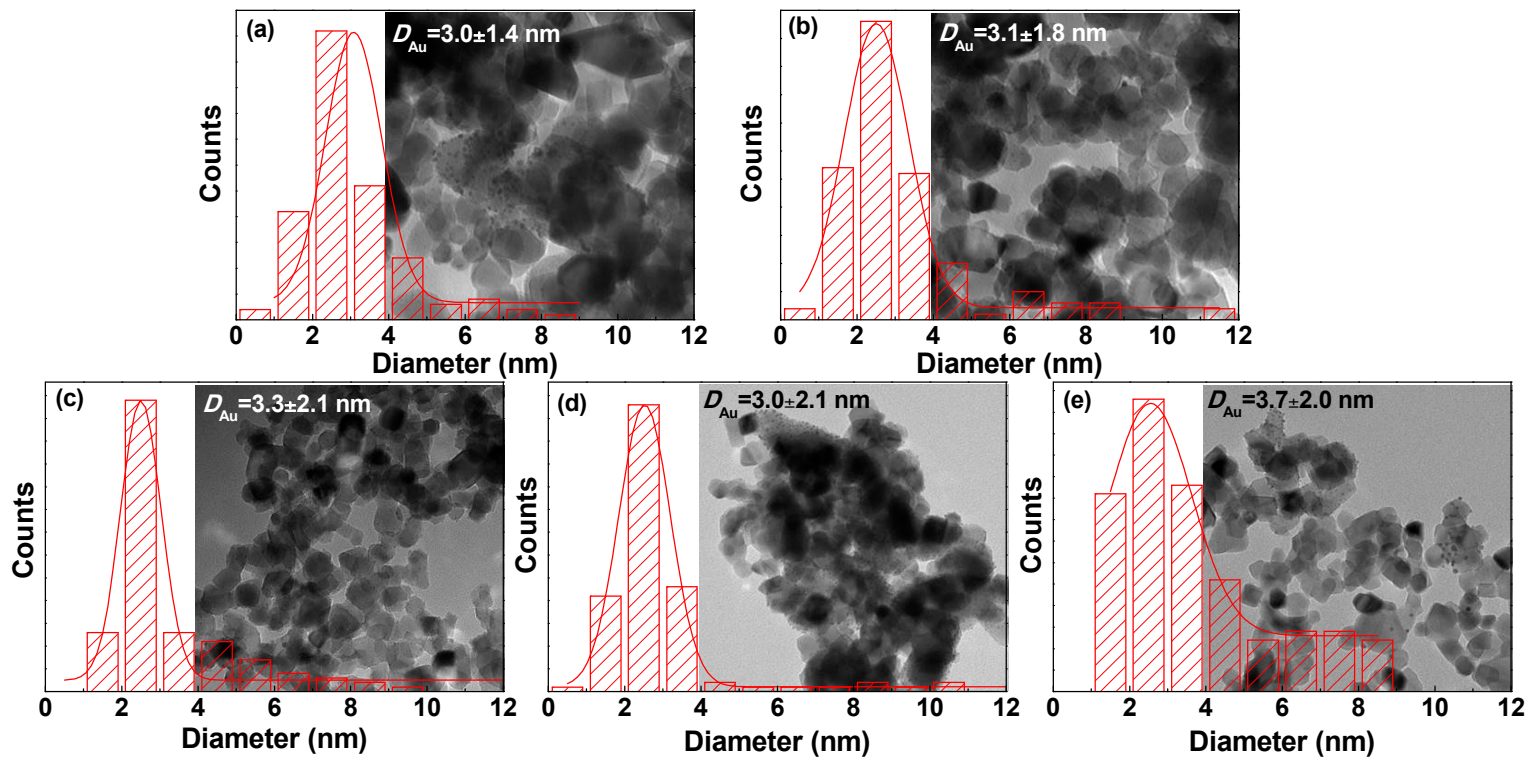

Figure 3. Typical transmission electron microscopy (TEM) images of (a) Au/P25-As; (b) Au/P25- ${ }_{2} \mathrm{P}$; (c) $\mathrm{Au} / \mathrm{P} 25-\mathrm{H}_{2} \mathrm{P}$; (d) Au/P25-ArP; (e) Au/P25-AirP, and the corresponding size distribution histograms of gold nanoparticles.

Table 1. Structure properties of the Au/P25 catalysts as prepared and activated by AP cold plasma, as well as P25 support.

\begin{tabular}{|c|c|c|c|c|c|}
\hline \multirow{2}{*}{ Samples } & \multicolumn{2}{|c|}{$2 \theta$ (degree) } & \multirow{2}{*}{$W_{\text {rutile }}(\%)$} & \multirow{2}{*}{$D_{\text {anatase }}(\mathrm{nm})$} & \multirow{2}{*}{$D_{\text {rutile }}(\mathrm{nm})$} \\
\hline & Anatase (101) & Rutile (110) & & & \\
\hline P25 & 25.3 & 27.5 & 17.9 & 21.1 & 31.0 \\
\hline $\mathrm{Au} / \mathrm{P} 25-\mathrm{As}$ & 25.2 & 27.4 & 17.3 & 22.3 & 28.4 \\
\hline $\mathrm{Au} / \mathrm{P} 25-\mathrm{O}_{2} \mathrm{P}$ & 25.3 & 27.4 & 19.1 & 21.0 & 27.9 \\
\hline $\mathrm{Au} / \mathrm{P} 25-\mathrm{H}_{2} \mathrm{P}$ & 25.2 & 27.4 & 20.1 & 20.1 & 29.1 \\
\hline $\mathrm{Au} / \mathrm{P} 25-\mathrm{ArP}$ & 25.3 & 27.4 & 17.2 & 21.5 & 28.0 \\
\hline $\mathrm{Au} / \mathrm{P} 25-\mathrm{AirP}$ & 25.2 & 27.4 & 17.4 & 21.6 & 31.0 \\
\hline
\end{tabular}

To investigate the optical properties of the samples, UV-Vis DRS spectra of the Au/P25 catalysts as prepared and activated by AP cold plasma with different working gases, as well as P25 support were measured, as shown in Figure 4. For all the samples, the absorption bands at shorter than $400 \mathrm{~nm}$ were ascribed to the P25 support [31], while the absorption bands in the visible region were attributed to gold species [32,33]. It is well known that metallic gold nanoparticles irradiated by visible light can lead to Localized Surface Plasmon Resonance (LSPR). A weak LSPR absorption peak for the as-prepared Au/P25-As is also observed, which is consistent with the XPS results (Table 2). The formation of the metallic gold species can be ascribed to the dissociation of the gold precursors due to their photosensitive property. Obviously, compared to Au/P25-As, the absorption for the $\mathrm{Au} / \mathrm{P} 25$ catalysts activated by AP cold plasma was dramatically enhanced in visible region, and LSPR absorption bands at ca $560 \mathrm{~nm}$ were observed due to the high content of metallic gold (Table 2). It confirms that cationic gold species can be reduced into their metallic state by AP cold plasma using various working gases. However, different LSPR absorption signals for the Au/P25 samples are observed, and the intensity of the LSPR peak follows the order: $\mathrm{Au} / \mathrm{P} 25-\mathrm{H}_{2} \mathrm{P}>\mathrm{Au} / \mathrm{P} 25-\mathrm{ArP}$ $>\mathrm{Au} / \mathrm{P} 25-\mathrm{AirP}>\mathrm{Au} / \mathrm{P} 25-\mathrm{O}_{2} \mathrm{P}$, which is consistent with the proportion of metallic gold (Table 2) according to the data taken from the result of XPS (Figure 5). The active ground and excited hydrogen atoms generated in cold plasma can not only reduce metal ions with positive standard potential, but also some with negative values [12]. Therefore, the $\mathrm{Au} / \mathrm{P} 25-\mathrm{H}_{2} \mathrm{P}$ demonstrates the most intense LSPR signal. The weakest LSPR absorption peak was observed for $\mathrm{Au} / \mathrm{P} 25-\mathrm{O}_{2} \mathrm{P}$, which may be ascribed to 
the strong quenching effect of electronegative oxygen gas on the energetic electrons. It can be verified by the intensity order of the LSPR absorption peak: Au/P25- $\mathrm{ArP}>\mathrm{Au} / \mathrm{P} 25-\mathrm{AirP}>\mathrm{Au} / \mathrm{P} 25-\mathrm{O}_{2} \mathrm{P}$.

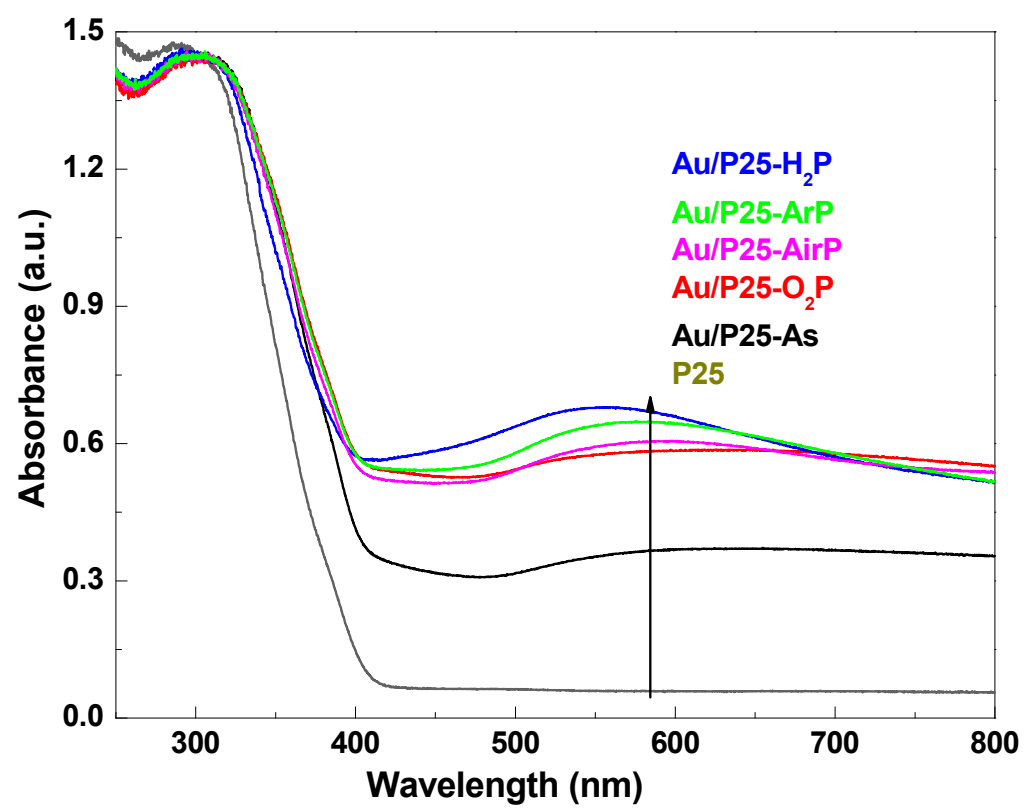

Figure 4. UV-Vis diffuse reflectance spectroscopy (DRS) spectra of the Au/P25 catalysts as prepared and activated by AP cold plasma using various working gases, as well as P25 support.
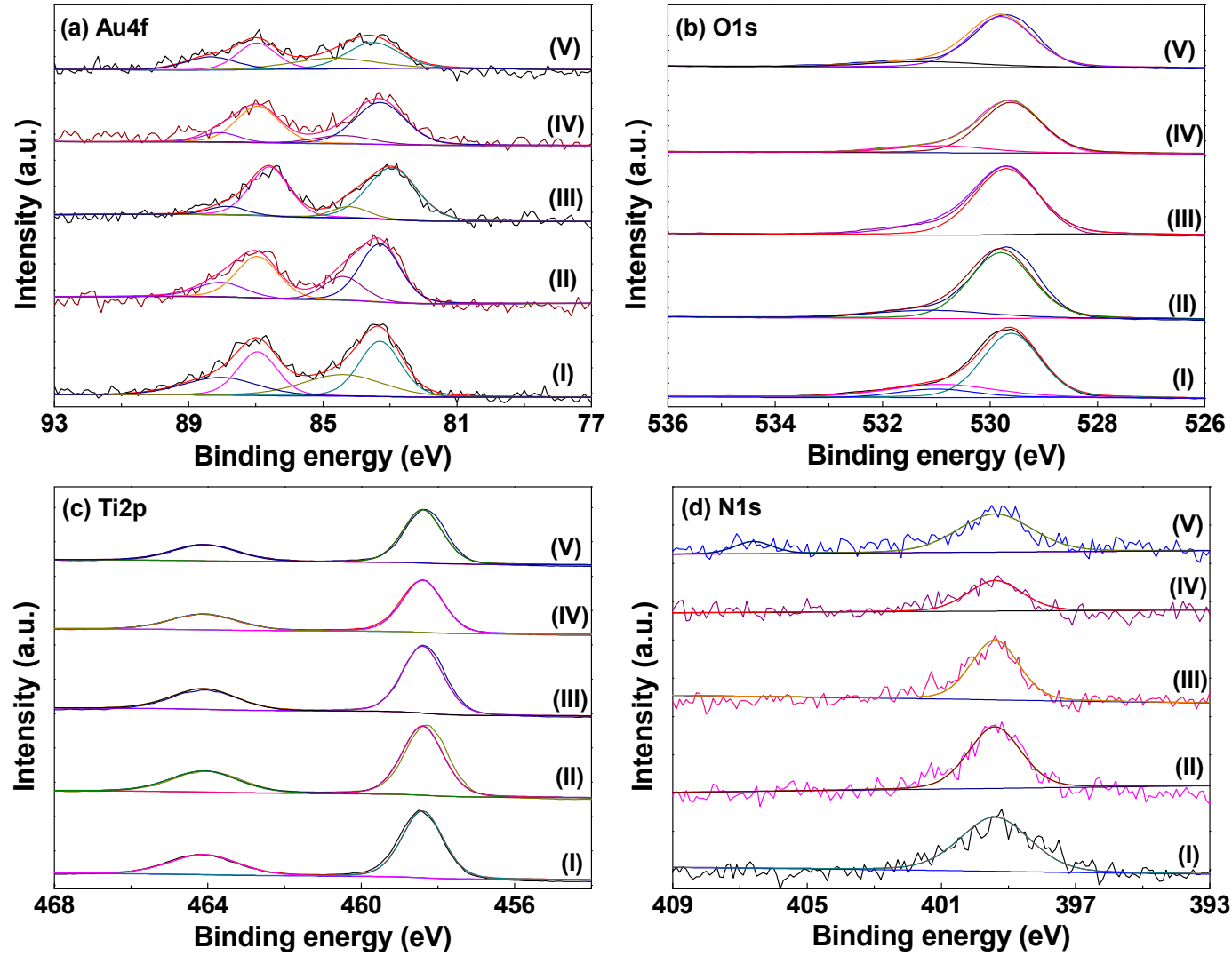

Figure 5. X-ray spectroscopy (XPS) spectra of (a) Au4f; (b) O1s; (c) Ti2p; and (d) N1s in (I) Au/P25-As; (II) $\mathrm{Au} / \mathrm{P} 25-\mathrm{O}_{2} \mathrm{P}$; (III) Au/P25- $\mathrm{H}_{2} \mathrm{P}$; (IV) Au/P25-ArP; and (V) Au/P25-AirP. 
Table 2. Gold nanoparticles diameter and XPS data of the Au/P25 catalysts.

\begin{tabular}{|c|c|c|c|c|c|c|}
\hline \multirow{2}{*}{ Samples } & \multirow{2}{*}{$\frac{D_{\mathrm{Au}}{ }^{\mathrm{a}}}{(\mathrm{nm})}$} & \multicolumn{2}{|c|}{ Binding Energy (eV) } & \multicolumn{2}{|c|}{ Proportion (at $\%$ ) } & \multirow{2}{*}{ Au/Ti Atomic Ratios } \\
\hline & & $\mathrm{Au}^{0} 4 f_{7 / 2}$ & $\mathrm{Au}^{+} 4 \mathrm{f}_{7 / 2}$ & $\mathrm{Au}^{0} /\left(\mathrm{Au}^{0}+\mathrm{Au}^{+}\right)$ & {$[\mathrm{O}]_{\mathrm{s}} /\left([\mathrm{O}]_{\mathrm{s}}+[\mathrm{O}]_{1}\right)$} & \\
\hline $\mathrm{Au} / \mathrm{P} 25-\mathrm{As}$ & $3.0 \pm 1.4$ & 83.3 & 84.4 & 56.9 & 27.4 & 0.023 \\
\hline $\mathrm{Au} / \mathrm{P} 25-\mathrm{O}_{2} \mathrm{P}$ & $3.1 \pm 1.8$ & 83.3 & 84.4 & 71.4 & 18.9 & 0.019 \\
\hline $\mathrm{Au} / \mathrm{P} 25-\mathrm{H}_{2} \mathrm{P}$ & $3.3 \pm 2.1$ & 82.9 & 84.1 & 86.2 & 15.4 & 0.018 \\
\hline $\mathrm{Au} / \mathrm{P} 25-\mathrm{ArP}$ & $3.0 \pm 2.1$ & 83.3 & 84.4 & 81.9 & 17.3 & 0.020 \\
\hline $\mathrm{Au} / \mathrm{P} 25-\mathrm{AirP}$ & $3.7 \pm 2.0$ & 83.3 & 84.5 & 78.3 & 16.5 & 0.018 \\
\hline
\end{tabular}

${ }^{\mathrm{a}}$ The average size of gold nanoparticles was obtained according to the TEM results.

TEM measurements were carried out to acquire average size and size distribution of gold nanoparticles, which are crucial during the process of gold catalysis [10,34]. Typical TEM images of $\mathrm{Au} / \mathrm{P} 25-\mathrm{As}, \mathrm{Au} / \mathrm{P} 25-\mathrm{O}_{2} \mathrm{P}, \mathrm{Au} / \mathrm{P} 25-\mathrm{H}_{2} \mathrm{P}, \mathrm{Au} / \mathrm{P} 25-\mathrm{ArP}, \mathrm{Au} / \mathrm{P} 25-\mathrm{AirP}$, and the corresponding size distribution histograms of gold nanoparticles are illustrated in Figure 3. Gold nanoparticles are finely dispersed on the P25 support in the Au/P25 samples. It has to be specified that the gold species are the mixture of oxidized and metallic gold species according to the XPS results (Table 2). Either metallic gold or oxidized gold can be distinguished from the $\mathrm{P} 25 \mathrm{TiO}_{2}$ support in the TEM images due to their contrast ratio. The average gold diameters for $\mathrm{Au} / \mathrm{P} 25-\mathrm{As}, \mathrm{Au} / \mathrm{P} 25-\mathrm{O}_{2} \mathrm{P}, \mathrm{Au} / \mathrm{P} 25-\mathrm{H}_{2} \mathrm{P}$, $\mathrm{Au} / \mathrm{P} 25-\mathrm{ArP}$, and $\mathrm{Au} / \mathrm{P} 25-\mathrm{AirP}$ are $3.0 \pm 1.4,3.1 \pm 1.8,3.3 \pm 2.1,3.0 \pm 2.1$, and $3.7 \pm 2.0 \mathrm{~nm}$, respectively (as summarized in Table 2). It was obvious that there is little change in average diameter of the gold nanoparticles for $\mathrm{Au} / \mathrm{P} 25-\mathrm{O}_{2} \mathrm{P}, \mathrm{Au} / \mathrm{P} 25-\mathrm{H}_{2} \mathrm{P}, \mathrm{Au} / \mathrm{P} 25-\mathrm{ArP}$ after AP cold plasma treatment. Meantime, the size distribution of gold nanoparticles became a little broader than that of Au/P25-As. These indicate that AP cold plasma did not significantly alter the size and size distribution of gold nanoparticles. However, larger particle size of gold nanoparticles is obtained for Au/P25-AirP after cold plasma treatment. Taking the weak influence of oxygen cold plasma on the size of gold nanoparticles into consideration, larger sizes of gold nanoparticles in Au/P25-AirP may result from the poisoning species $\left[\mathrm{NO}_{\mathrm{y}}\right]_{\mathrm{s}}$ during nitrogen and oxygen discharge in air cold plasma [24]. This can be confirmed by the XPS spectrum of N1s for Au/P25-AirP (Figure 5d).

The chemical state of gold species, surface oxygen, and other species play important roles in the activity for supported gold catalysts [23,35]. To further investigate the influence of AP cold plasma activation, XPS spectra of Au/P25-As, Au/P25- ${ }_{2} \mathrm{P}, \mathrm{Au} / \mathrm{P} 25-\mathrm{H}_{2} \mathrm{P}, \mathrm{Au} / \mathrm{P} 25-\mathrm{ArP}$, and Au/P25-AirP are recorded, as shown in Figure 5. No Cl ions can be detected from the XPS spectra of Cl1s in the Au/P25 samples (not shown here) due to the rinsing of the aqueous ammonia solution and deionized water. In Figure 5a, the XPS spectra of Au4f in these samples can be fitted with two peaks corresponding to metallic $\mathrm{Au}^{0}$ and $\mathrm{Au}^{+}$[26], revealing that $\mathrm{AP}$ cold plasma can reduce the gold precursor species into metallic state gold. The proportion of metallic $\mathrm{Au}^{0}$ and the binding energies of $\mathrm{Au} 4 \mathrm{f}_{7 / 2}$ for these samples are summarized in Table 2. The proportion of the metallic $\mathrm{Au}^{0}$ in the samples follows the order: $\mathrm{Au} / \mathrm{P} 25-\mathrm{H}_{2} \mathrm{P}>\mathrm{Au} / \mathrm{P} 25-\mathrm{ArP}>\mathrm{Au} / \mathrm{P} 25-\mathrm{AirP}>\mathrm{Au} / \mathrm{P} 25-\mathrm{O}_{2} \mathrm{P}$, which is in line with the intensity sequence of the LSPR peak in UV-Vis DRS spectra (Figure 4). Interestingly, $0.4 \mathrm{eV}$ redshift in the binding energy of $\mathrm{Au}_{4 / 2}$ for $\mathrm{Au} / \mathrm{P} 25-\mathrm{H}_{2} \mathrm{P}$ is observed, which can be explained by the following reasons. One the one hand, AP hydrogen cold plasma for synthesizing supported metal catalysts generally may lead to redshift of the binding energy due to the enhanced strong metal-support interaction $[18,36]$. On the other hand, $\mathrm{Au} / \mathrm{P} 25-\mathrm{H}_{2} \mathrm{P}$ has the highest proportion of metallic $\mathrm{Au}^{0}$, which may also enhance the redshift of the binding energy [36].

Surface oxygen species are beneficial to the formation of active intermediates during $\mathrm{CO}$ oxidation over supported gold catalysts [6,37]. In Figure 5b, O1s spectra for the Au/P25 samples are illustrated, which can be deconvoluted into two peaks at 529.6 and $530.9 \mathrm{eV}$, ascribed to crystal lattice oxygen $[\mathrm{O}]_{1}$ and surface oxygen species $[\mathrm{O}]_{\mathrm{s}}$, respectively [38]. Based on individual peak area, $[\mathrm{O}]_{\mathrm{s}}$ concentration in the oxygen species were calculated and listed in Table 2. The order of $[\mathrm{O}]_{\mathrm{S}}$ concentration for all the Au/P25 catalysts was Au/P25-As > Au/P25- $\mathrm{O}_{2} \mathrm{P}>\mathrm{Au} / \mathrm{P} 25-\mathrm{ArP}>\mathrm{Au} / \mathrm{P} 25-\mathrm{AirP}>\mathrm{Au} / \mathrm{P} 25-\mathrm{H}_{2} \mathrm{P}$, 
indicating that cold plasma activation can lead to the decline of $[\mathrm{O}]_{s}$ concentration and working gas play important roles in $[\mathrm{O}]_{\mathrm{s}}$ concentration. The significant decrease in $[\mathrm{O}]_{\mathrm{s}}$ concentration for $\mathrm{Au} / \mathrm{P} 25-\mathrm{H}_{2} \mathrm{P}$ may result from the consumption of $[\mathrm{O}]_{\mathrm{s}}$ by the hydrogen species [27]. Combined with the results of the proportions of metallic $\mathrm{Au}^{0}$ and $[\mathrm{O}]_{\mathrm{s}}$ (Table 2), it can be concluded that AP cold plasma can not only decompose gold precursor into metallic $\mathrm{Au}^{0}$ but also form active $[\mathrm{O}]_{\mathrm{s}}$ on the P25 surface.

Figure $5 c$ presents the Ti2p XPS spectra of the Au/P25 samples. The peaks at 458.4 and $464.1 \mathrm{eV}$ are attributed to $\mathrm{Ti}^{4+}$ of $\mathrm{P} 25$ support for the $\mathrm{Au} / \mathrm{P} 25$ catalysts, confirming that the chemical environment of support didn't vary after cold plasma activation [23,39]. In Figure 5d, N1s spectra for the Au/P25 catalysts are also investigated. The peaks at $399.4 \mathrm{eV}$ for all the Au/P25 catalysts were ascribed to chemisorbed $\gamma-\mathrm{N}_{2}$ [40]. Interestingly, a new and weak peak at $406.6 \mathrm{eV}$ appeared for $\mathrm{Au} / \mathrm{P} 25-\mathrm{AirP}$, which can be attributed to $\left[\mathrm{NO}_{\mathrm{x}}\right]_{\mathrm{S}}$ due to the air plasma treatment $[24,25]$. The atomic ratios of $\mathrm{Au} / \mathrm{Ti}$ for the Au/P25 samples are determined according to the XPS results and summarized in Table 2. $\mathrm{The} \mathrm{Au} / \mathrm{Ti}$ atomic ratio for $\mathrm{Au} / \mathrm{P} 25-\mathrm{As}$ is 0.023 . However, they are decreased after AP cold plasma activation due to the dissociation of the gold precursor species. In spite of this, there is no obvious difference for the Au/P25 samples activated by AP cold plasma using different working gases.

Figure 6 presents $\mathrm{CO}$ conversion versus reaction temperature over the Au/P25 catalysts prepared by AP cold plasma activation using various working gases, as well as the as-prepared Au/P25-As. All of the $\mathrm{Au} / \mathrm{P} 25$ catalysts exhibit high $\mathrm{CO}$ oxidation activity. $\mathrm{CO}$ oxidation activity over the Au/P25 catalysts follows the order: $\mathrm{Au} / \mathrm{P} 25-\mathrm{O}_{2} \mathrm{P}>\mathrm{Au} / \mathrm{P} 25-\mathrm{As}>\mathrm{Au} / \mathrm{P} 25-\mathrm{ArP} \approx \mathrm{Au} / \mathrm{P} 25-\mathrm{H}_{2} \mathrm{P}>\mathrm{Au} / \mathrm{P} 25-\mathrm{AirP}$. Catalytic performance of the $\mathrm{Au} / \mathrm{P} 25$ catalysts is closely related with the working atmosphere of $\mathrm{AP}$ cold plasma. Au/P25-ArP, Au/P25- $\mathrm{H}_{2} \mathrm{P}$, and Au/P25-AirP obtained by AP argon, hydrogen, and air cold plasma activation show poorer $\mathrm{CO}$ oxidation activity than the as-prepared $\mathrm{Au} / \mathrm{P} 25-\mathrm{As}$ catalyst, and Au/P25-AirP presents the poorest catalytic activity. Interestingly, AP oxygen cold plasma activation can significantly enhance the catalytic performance of the Au/P25 catalyst. $100 \% \mathrm{CO}$ conversion temperatures for $\mathrm{Au} / \mathrm{P} 25-\mathrm{O}_{2} \mathrm{P}$ is $40{ }^{\circ} \mathrm{C}$, which is $30^{\circ} \mathrm{C}$ lower than that over the as-prepared $\mathrm{Au} / \mathrm{P} 25-\mathrm{As}$ catalyst.

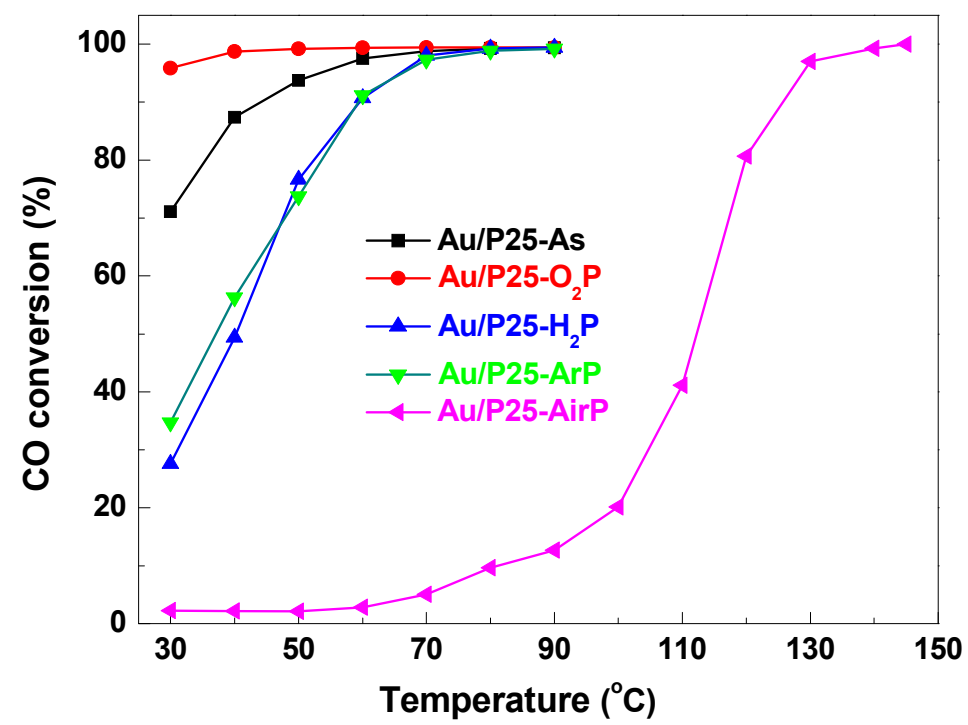

Figure 6. $\mathrm{CO}$ conversion over the Au/P25 catalysts activated by AP cold plasma using various working gases, as well as the as-prepared Au/P25-As.

AP cold plasma activation with oxygen, argon, and hydrogen as working gas has no significance influence on the size of gold nanoparticles $\left(D_{\mathrm{Au}}=3.0-3.3 \mathrm{~nm}\right)$. AP cold plasma activation of the $\mathrm{Au} / \mathrm{P} 25-\mathrm{As}$ catalysts may not only lead to the decomposition of the gold precursor species and formation of active $[\mathrm{O}]_{\mathrm{s}}$ species, but also can result in the removal of active $[\mathrm{O}]_{\mathrm{s}}$ species after longer AP 
cold plasma treatment time [29]. The decomposed gold species containing oxidized and metallic gold species can be transformed into active metallic gold species [26]. As a consequence, [O]s species play important roles in $\mathrm{CO}$ oxidation. The highest $[\mathrm{O}]_{\mathrm{s}}$ is observed for Au/P25-As (Table 2). Therefore, it seems that it should exhibit the highest $\mathrm{CO}$ oxidation activity. In previous work [26], it has been proved that some $[\mathrm{O}]_{\mathrm{s}}$ in the as-prepared $\mathrm{Au} / \mathrm{P} 25-\mathrm{As}$ sample will be rapidly consumed during the reaction, and lower $\mathrm{CO}$ oxidation activity will be obtained. In addition, the high $\mathrm{Au} / \mathrm{Ti}$ atomic ratio in $\mathrm{Au} / \mathrm{P} 25-\mathrm{As}$ is also beneficial to the high $\mathrm{CO}$ oxidation activity. For $\mathrm{Au} / \mathrm{P} 25-\mathrm{O}_{2} \mathrm{P}$ prepared by AP oxygen cold plasma activation, the gold precursor species can be well decomposed, and high concentration of $[\mathrm{O}]_{s}$ species are obtained. Therefore, $\mathrm{Au} / \mathrm{P} 25-\mathrm{O}_{2} \mathrm{P}$ presents the highest catalytic activity among the $\mathrm{Au} / \mathrm{P} 25$ catalysts. While, $\mathrm{Au} / \mathrm{P} 25-\mathrm{ArP}$ and $\mathrm{Au} / \mathrm{P} 25-\mathrm{H}_{2} \mathrm{P}$ with less concentration of $[\mathrm{O}]_{\mathrm{s}}$ species show poorer $\mathrm{CO}$ oxidation performance. $\mathrm{Au} / \mathrm{P} 25$-AirP presents the poorest $\mathrm{CO}$ oxidation catalytic activity among the $\mathrm{Au} / \mathrm{P} 25$ catalysts, which may be ascribed to the larger size of gold nanoparticles $\left(D_{\mathrm{Au}}=3.7 \mathrm{~nm}\right)$, low concentration of active $[\mathrm{O}]_{s}$, as well as the poisoning $\left[\mathrm{NO}_{\mathrm{x}}\right]_{\mathrm{s}}[24,25]$.

\section{Conclusions}

AP cold plasma was adopted to activate the Au/P25-As catalyst prepared by a modified impregnation method, and the influence of working gas on the structure and performance of the obtained $\mathrm{Au} / \mathrm{P} 25$ catalysts was investigated. XRD analyses confirm that supporting gold and AP cold plasma activation have little effect on the P25 support. All of the Au/P25 catalysts exhibit high CO catalytic oxidation activity. Catalytic performance of the Au/P25 catalysts is closely related with the working atmosphere of AP cold plasma. $\mathrm{CO}$ oxidation activity over the Au/P25 catalysts follows the order: $\mathrm{Au} / \mathrm{P} 25-\mathrm{O}_{2} \mathrm{P}>\mathrm{Au} / \mathrm{P} 25-\mathrm{As}>\mathrm{Au} / \mathrm{P} 25-\mathrm{ArP} \approx \mathrm{Au} / \mathrm{P} 25-\mathrm{H}_{2} \mathrm{P}>\mathrm{Au} / \mathrm{P} 25-\mathrm{AirP}$. The poor catalytic performance of $\mathrm{Au} / \mathrm{P} 25-\mathrm{ArP}$ and $\mathrm{Au} / \mathrm{P} 25-\mathrm{H}_{2} \mathrm{P}$ is ascribed to the lower concentration of $[\mathrm{O}]_{\mathrm{s}}$ species. $\mathrm{Au} / \mathrm{P} 25-\mathrm{AirP}$ presents the poorest $\mathrm{CO}$ oxidation catalytic activity among the $\mathrm{Au} / \mathrm{P} 25$ catalysts, which may be ascribed to the larger size of gold nanoparticles, low concentration of active $[\mathrm{O}]_{\mathrm{s}}$, as well as the poisoning $\left[\mathrm{NO}_{\mathrm{x}}\right]_{\mathrm{s}} .100 \% \mathrm{CO}$ conversion temperatures for $\mathrm{Au} / \mathrm{P} 25-\mathrm{O}_{2} \mathrm{P}$ is $40{ }^{\circ} \mathrm{C}$, which is $30{ }^{\circ} \mathrm{C}$ lower than that over the as-prepared $\mathrm{Au} / \mathrm{P} 25-\mathrm{As}$ catalyst. The excellent $\mathrm{CO}$ oxidation activity over $\mathrm{Au} / \mathrm{P} 25-\mathrm{O}_{2} \mathrm{P}$ is mainly attributed to the efficient decomposition of gold precursor species, small size of gold nanoparticles, and the high concentration of $[\mathrm{O}]_{\mathrm{s}}$ species. AP oxygen cold plasma activation is found to be an efficient method for synthesizing high performance Au/P25 catalysts.

Author Contributions: Conceptualization, L.D. and F.Y.; Data curation, J.Z. and D.D.; Investigation, J.Z. and D.D.; Project administration, L.D.; Supervision, L.D. and X.Z.; Writing—original draft, L.D.; Writing—review \& editing, X.Z.

Acknowledgments: This research was funded by National Natural Science Foundation of China (Grant No. 21773020, 11505019, 21673026), Liaoning Innovative Talents in University (Grant No. LR2017025), Liaoning Natural Science Foundation (Grant No. 20180550085).

Conflicts of Interest: The authors declare no conflict of interest.

\section{References}

1. Haruta, M.; Kobayashi, T.; Sano, H.; Yamada, N. Novel gold catalysts for the oxidation of carbon monoxide at a temperature far below $0{ }^{\circ} \mathrm{C}$. Chem. Lett. 1987, 16, 405-408. [CrossRef]

2. Haruta, M.; Yamada, N.; Kobayashi, T.; Iijima, S. Gold catalysts prepared by coprecipitation for low-temperature oxidation of hydrogen and of carbon monoxide. J. Catal. 1989, 115, 301-309. [CrossRef]

3. Christensen, C.H.; Nørskov, J.K. Green gold catalysis. Science 2010, 327, 278-279. [CrossRef] [PubMed]

4. Saavedra, J.; Doan, H.A.; Pursell, C.J.; Grabow, L.C.; Chandler, B.D. The critical role of water at the gold-titania interface in catalytic CO oxidation. Science 2014, 345, 1599-1602. [CrossRef] [PubMed]

5. Wang, Y.; Widmann, D.; Behm, R.J. Influence of $\mathrm{TiO}_{2}$ bulk defects on $\mathrm{CO}$ adsorption and $\mathrm{CO}$ oxidation on $\mathrm{Au} / \mathrm{TiO}_{2}$ : Electronic metal-support interactions (EMSIs) in supported Au catalysts. ACS Catal. 2017, 7, 2339-2345. [CrossRef]

6. Kung, H.H.; Kung, M.C.; Costello, C.K. Supported Au catalysts for low temperature CO oxidation. J. Catal. 2003, 216, 425-432. [CrossRef] 
7. Valden, M.; Lai, X.; Goodman, D.W. Onset of catalytic activity of gold clusters on Titania with the appearance of nonmetallic properties. Science 1998, 281, 1647-1650. [CrossRef] [PubMed]

8. Widmann, D.; Liu, Y.; Schüth, F.; Behm, R.J. Support effects in the Au-catalyzed CO oxidation-correlation between activity, oxygen storage capacity, and support reducibility. J. Catal. 2010, 276, 292-305. [CrossRef]

9. Delannoy, L.; El, H.N.; Musi, A.; To, N.N.L.; Krafft, J.M.; Louis, C. Preparation of supported gold nanoparticles by a modified incipient wetness impregnation method. J. Phys. Chem. B 2006, 110, 22471-22478. [CrossRef] [PubMed]

10. Akita, T.; Lu, P.; Ichikawa, S.; Tanaka, K.; Haruta, M. Analytical TEM study on the dispersion of Au nanoparticles in Au/P25 catalyst prepared under various temperatures. Surf. Interface Anal. 2001, 31, 73-78. [CrossRef]

11. Overbury, S.H.; Schwartz, V.; Mullins, D.R.; Yan, W.; Dai, S. Evaluation of the Au size effect: CO oxidation catalyzed by Au/P25. J. Catal. 2006, 241, 56-65. [CrossRef]

12. Di, L.B.; Zhang, J.S.; Zhang, X.L. A review on the recent progress, challenges and perspectives of atmospheric-pressure cold plasma for preparation of supported metal catalysts. Plasma Process. Polym. 2018, 15, 1700234. [CrossRef]

13. Liu, C.J.; Zhao, Y.; Li, Y.; Zhang, D.S.; Chang, Z.; Bu, X.H. Perspectives on electron-assisted reduction for preparation of highly dispersed noble metal catalysts. ACS Sustain. Chem. Eng. 2014, 2, 3-13. [CrossRef]

14. Wang, Z.; Zhang, Y.; Neyts, E.C.; Cao, X.; Zhang, X.; Jang, B.W.L.; Liu, C.J. Catalyst Preparation with Plasmas: How Does It Work? ACS Catal. 2018, 8, 2093-2110. [CrossRef]

15. Xu, Z.J.; Qi, B.; Di, L.B.; Zhang, X.L. Partially crystallized Pd nanoparticles decorated $\mathrm{TiO}_{2}$ prepared by atmospheric-pressure cold plasma and its enhanced photocatalytic performance. J. Energy Chem. 2014, 23, 679-683. [CrossRef]

16. Zou, J.J.; Zhang, Y.P.; Liu, C.J. Reduction of supported noble-metal ions using glow discharge plasma. Langmuir 2006, 22, 11388-11394. [CrossRef] [PubMed]

17. Wang, W.; Wang, Z.; Wang, J.; Zhong, C.J.; Liu, C.J. Highly active and stable Pt-Pd alloy catalysts synthesized by room-temperature electron reduction for oxygen reduction reaction. Adv. Sci. 2017, 4, 1600486. [CrossRef] [PubMed]

18. Di, L.B.; Duan, D.Z.; Park, D.W.; Ahn, W.S.; Lee, B.J.; Zhang, X.L. Cold plasma for synthesizing high performance bimetallic $\mathrm{PdCu}$ catalysts: Effect of reduction sequence and $\mathrm{Pd} / \mathrm{Cu}$ atomic ratios. Top. Catal. 2017, 60, 925-933. [CrossRef]

19. Furusho, H.; Kitano, K.; Hamaguchi, S.; Nagasaki, Y. Preparation of stable water-dispersible PEGylated gold nanoparticles assisted by nonequilibrium atmospheric-pressure plasma jets. Chem. Mater. 2009, 21, 3526-3535. [CrossRef]

20. Sharma, R.; Rimmer, R.D.; Gunamgari, J.; Shekhawat, R.S.; Davis, B.J.; Mazumder, M.K.; Lindquist, D.A. Plasma-assisted activation of supported $\mathrm{Au}$ and Pd catalysts for CO oxidation. IEEE Trans. Ind. Appl. 2005, 41, 1373-1376. [CrossRef]

21. Liu, X.; Mou, C.Y.; Lee, S.; Li, Y.; Secrest, J.; Jang, B.W.-L. Room temperature $\mathrm{O}_{2}$ plasma treatment of $\mathrm{SiO}_{2}$ supported Au catalysts for selective hydrogenation of acetylene in the presence of large excess of ethylene. J. Catal. 2012, 285, 152-159. [CrossRef]

22. Wei, Z.; Liu, C. Synthesis of monodisperse gold nanoparticles in ionic liquid by applying room temperature plasma. Mater. Lett. 2011, 65, 353-355. [CrossRef]

23. Zhang, S.; Li, X.S.; Zhu, B.; Liu, J.L.; Zhu, X.; Zhu, A.M.; Jang, B.W.-L. Atmospheric-pressure $\mathrm{O}_{2}$ plasma treatment of Au/P25 catalysts for CO oxidation. Catal. Today 2015, 256, 142-147. [CrossRef]

24. Fan, H.Y.; Shi, C.; Li, X.S.; Zhang, S.; Liu, J.L.; Zhu, A.M. In-situ plasma regeneration of deactivated Au/P25 nanocatalysts during $\mathrm{CO}$ oxidation and effect of $\mathrm{N}_{2}$ content. Appl. Catal. B Environ. 2012, 119, 49-55. [CrossRef]

25. Zhu, B.; Li, X.S.; Liu, J.L.; Liu, J.B.; Zhu, X.; Zhu, A.M. In-situ regeneration of Au nanocatalysts by atmospheric-pressure air plasma: Significant contribution of water vapor. Appl. Catal. B Environ. 2015, 179, 69-77. [CrossRef]

26. Deng, X.Q.; Zhu, B.; Li, X.S.; Liu, J.L.; Zhu, X.; Zhu, A.M. Visible-light photocatalytic oxidation of CO over plasmonic Au/P25: Unusual features of oxygen plasma activation. Appl. Catal. B Environ. 2016, 188, 48-55. [CrossRef] 
27. Di, L.B.; Zhan, Z.B.; Zhang, X.L.; Qi, B.; Xu, W.J. Atmospheric-Pressure DBD Cold Plasma for Preparation of High Active Au/P25 Catalysts for Low-Temperature CO Oxidation. Plasma Sci. Technol. 2016, 18, 544-548. [CrossRef]

28. Di, L.B.; Duan, D.Z.; Zhang, X.L.; Qi, B.; Zhan, Z.B. Effect of $\mathrm{TiO}_{2}$ Crystal Phase and Preparation Method on the Catalytic Performance of $\mathrm{Au} / \mathrm{TiO}_{2}$ for CO Oxidation. IEEE Trans. Plasma Sci. 2016, 44, 2692-2698. [CrossRef]

29. Zhang, X.L.; Xu, W.W.; Duan, D.Z.; Park, D.-W.; Di, L.B. Atmospheric-pressure oxygen cold plasma for synthesizing $\mathrm{Au} / \mathrm{TiO}_{2}$ catalysts: Effect of discharge voltage and discharge time. IEEE Trans. Plasma Sci. 2018, 46, 2776-2781. [CrossRef]

30. Zhang, H.; Banfield, J.F. Understanding polymorphic phase transformation behavior during growth of nanocrystalline aggregates: Insights from $\mathrm{TiO}_{2}$. J. Phys. Chem. B 2000, 104, 3481-3487. [CrossRef]

31. Di, L.B.; Xu, Z.J.; Zhang, X.L. Atmospheric-pressure cold plasma for synthesizing Ag modified Degussa P25 with visible light activity using dielectric barrier discharge. Catal. Today 2013, 211, 143-146. [CrossRef]

32. Zanella, R.; Giorgio, S.; Shin, C.H.; Henry, C.R.; Louisa, C. Characterization and reactivity in CO oxidation of gold nanoparticles supported on $\mathrm{TiO}_{2}$ prepared by deposition-precipitation with $\mathrm{NaOH}$ and urea. J. Catal. 2004, 222, 357-367. [CrossRef]

33. Orendorff, C.J.; Sau, T.K.; Murphy, C.J. Shape-dependent plasmon-resonant gold nanoparticles. Small 2006, 2, 636-639. [CrossRef] [PubMed]

34. Haruta, M. Size-and support-dependency in the catalysis of gold. Catal. Today 1997, 36, 153-166. [CrossRef]

35. Delannoy, L.; Weiher, N.; Tsapatsaris, N.; Beesley, A.M.; Nchari, L.; Schroeder, S.L.M.; Louis, C. Reducibility of supported gold (III) precursors: Influence of the metal oxide support and consequences for CO oxidation activity. Top. Catal. 2007, 44, 263-273. [CrossRef]

36. Di, L.B.; Zhang, X.L.; Xu, Z.J.; Wang, K. Atmospheric-pressure cold plasma for preparation of high performance $\mathrm{Pt} / \mathrm{TiO}_{2}$ photocatalyst and its mechanism. Plasma Chem. Plasma Process. 2014, 34, 301-311. [CrossRef]

37. Daniells, S.T.; Overweg, A.R.; Makkee, M.; Moulijn, J.A. The mechanism of low-temperature CO oxidation with $\mathrm{Au} / \mathrm{Fe}_{2} \mathrm{O}_{3}$ catalysts: A combined Mössbauer, FT-IR, and TAP reactor study. J. Catal. 2005, 230, 52-65. [CrossRef]

38. Liu, L.; Gu, X.; Cao, Y.; Yao, X.; Zhang, L.; Tang, C.; Gao, F.; Dong, L. Crystal-plane effects on the catalytic properties of $\mathrm{Au} / \mathrm{TiO}_{2}$. ACS Catal. 2013, 3, 2768-2775. [CrossRef]

39. Yang, Q.Y.; Zhu, Y.; Tian, L.; Pei, Y.; Qiao, M.H.; Fan, K.N. Influence of $\mathrm{Au} / \mathrm{TiO}_{2}$ Catalyst Preparation Parameters on the Selective Hydrogenation of Crotonaldehyde. Acta Phys. Chim. Sin. 2009, 25, 1853-1860. [CrossRef]

40. Di, L.B.; Shi, C.; Li, X.S.; Liu, J.L.; Zhu, A.M. Uniformity, structure, and photocatalytic activity of TiO films $^{2}$ deposited by atmospheric-pressure linear cold plasma. Chem. Vap. Depos. 2012, 18, 309-314. [CrossRef] 